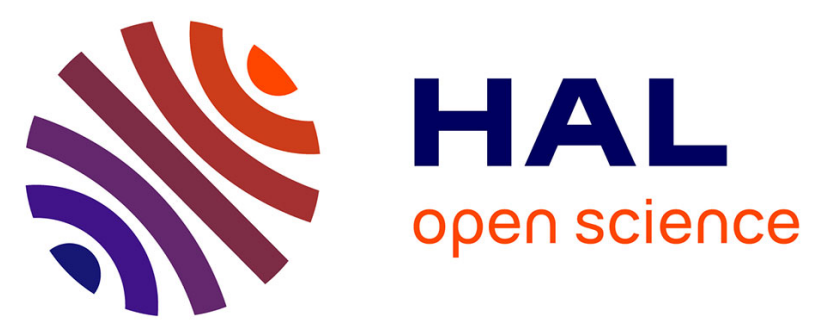

\title{
Variation of wood density and hydraulic properties of Douglas-fir (Pseudotsuga menziesii (Mirb.) Franco) clones related to a heat and drought waves in France
} Guillermina G. Dalla Salda, Alejandro Martinez Martinez-Meier, Hervé H. Cochard, Philippe P. Rozenberg

\section{To cite this version:}

Guillermina G. Dalla Salda, Alejandro Martinez Martinez-Meier, Hervé H. Cochard, Philippe P. Rozenberg. Variation of wood density and hydraulic properties of Douglas-fir (Pseudotsuga menziesii (Mirb.) Franco) clones related to a heat and drought waves in France. Forest Ecology and Management, 2009, 257 (1), pp.182-189. 10.1016/j.foreco.2008.08.019 . hal-00964863

\section{HAL Id: hal-00964863 https://hal.science/hal-00964863}

Submitted on 30 May 2020

HAL is a multi-disciplinary open access archive for the deposit and dissemination of scientific research documents, whether they are published or not. The documents may come from teaching and research institutions in France or abroad, or from public or private research centers.
L'archive ouverte pluridisciplinaire $\mathbf{H A L}$, est destinée au dépôt et à la diffusion de documents scientifiques de niveau recherche, publiés ou non, émanant des établissements d'enseignement et de recherche français ou étrangers, des laboratoires publics ou privés. 


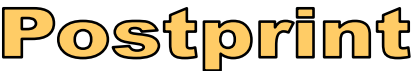

Version définitive du manuscrit publié dans / Final version of the manuscript published in :

In Forest Ecology and Management. 2009, 257(1), 182-189

Variation of wood density and hydraulic properties of Douglas-fir (Pseudotsuga menziesii

(Mirb.) Franco) clones related to a heat and drought wave in France.

Guillermina Dalla-Salda ${ }^{*}$, Alejandro Martinez-Meier ${ }^{c}$, Hervé Cochard ${ }^{\mathrm{d}}$ and Philippe Rozenberg ${ }^{\mathrm{a}}$.

${ }^{\text {a }}$ INRA (Institut National de la Recherche Agronomique) Orléans, Unité Amélioration Génétique et Physiologie Forestières, 2163 Avenue de la Pomme de Pin, CS 40001 ARDON, 45075 ORLEANS Cedex 2, France

b INTA (Instituto Nacionl de Tecnología Agropecuaria) Bariloche, Grupo de Ecología Forestal. C.C. 277, (8400), San Carlos de Bariloche, Argentina.

${ }^{\text {c }}$ INTA (Instituto Nacionl de Tecnología Agropecuaria) Bariloche, Unidad de Genética Forestal. C.C. 277, (8400), San Carlos de Bariloche, Argentina.

${ }^{\mathrm{d}}$ INRA (Institut National de la Recherche Agronomique) Clermont-Ferrand, PIAF. Site de Crouël. Avenue du Brézet, 63100 Clermont-Ferrand, France.

*Telephone number: $+33-+238417873$

Fax number: $+33-+238417879$

Email: dallasalda@orleans.inra.fr

Keywords: tree-ring conductivity, cavitation, wood density, adaptation, climate changes 


\section{ABSTRACT}

Drought response of three Douglas-fir clones (slow, intermediate and fast growing) inhabiting two different climatic regimes in France was examined. We used the hydraulic conductivity and the percent loss of conductivity due to embolism from stems and branches as well as wood microdensity measurements to determine the role of genetics in the control of embolism in this species. Conductivity and tree-ring's microdensity variables (ring width: RW, mean ring density: MRD, minimum ring density: MID and maximum ring density: MAD) were compared in growth rings in all three clones during a typical year (2002) vs. an extremely dry year (2003). A new method was developed in order to assess axial hydraulic specific conductivity (Ks) within tree rings. The results show that branches are more resistant to embolism than stems, and that there are significant differences in embolism resistance among the clones between the two sites. Ks varied between years, site and clone but the site exerted the most significant effect. Lartimache (more humid site during 2003) trees showed substantially higher Ks than those inhabiting Chassenoix (strongly affected by the 2003 heat and drought wave site). Wood analysis showed a significant year effect for all ring variables and a significant clone effect for all ring variables except for MAD, while the site effect was significant for MRD and MAD.. The existence of a genetic control for the study traits indicates that Douglas-fir populations introduced in France may have a selection potential to face extreme climate events like the 2003 heat and drought wave. 


\section{INTRODUCTION}

The drought and heat wave which occurred in Europe in summer 2003 (Meehl and Tebaldi 2004; Levinson and Waple 2004; Rebetz et al., 2006) strongly affected trees. Visible consequences were reported in several regions of France, from partial crown necrosis to the death of some individuals (Bréda et al., 2004, Rozenberg and Pâques 2004). Douglas-fir, an important productive forest species in temperate regions, originating from North-West America and abundantly introduced in France, was one of the species strongly affected (Département de la Santé des Forêts 2004, Martinez Meier et al., 2008).

A drought is characterized by a strong decrease of water availability in the soil. According to Bréda et al. (2006) the first reaction of a tree to this diminution is the decrease of transpiration by stomatal closure, generally accompanied by a growth reduction. Such a significant growth reduction was observed in Douglas-fir by Martinez Meier et al. (2008) in the ring formed during the year 2003, noticeably in a French site severely affected by the 2003 heat and drought wave. They also showed that this growth reduction was accompanied by a wood density decrease. Douglas-fir was susceptible to the 2003 heat and drought wave and this response was recently found to be genetically controlled (Martinez-Meier et al. 2008). But is this variation meaningful from an adaptive point of view? In other words, does the genetic variation of the response to the climate of the year 2003 affect this species fitness?

One way to answer this question is to simultaneously investigate the variation of ring density components with that of traits well known to have an adaptive significance and to affect the species fitness.

When the length and the intensity of a drought increase, cavitation may occur in xylem conduits (Bacelar et al., 2007) followed by early mortality of roots and twigs and, ultimately, by tree death (Bréda et al., 2006). The hydraulic-failure hypothesis predicts that high evaporative demand and reduced soil water supply cause xylem conduits to cavitate, stopping 
the flow of water and desiccating plant tissues. Hydraulic failure occurs when drought is intense enough to lead plants to run out of water before they run out of carbon (McDowell et al. 2008). Vulnerability to cavitation is influenced by the structure of the xylem (Hacke et al., 2001a; Domec and Gartner, 2002a). According to several authors (Stratton et al., 2000; Hacke et al., 2001a; Bucci et al., 2004), it is particularly closely related to the proportion of lumen cell wall in the xylem: thicker cell walls and smaller diameter lumens could help trees to preserve their hydraulic system (Sperry et al., 2006; Pittermann et al., 2006). Conduits' length and diameter and wall thickness can also influence flow resistance and wall collapse (Sperry et al., 2006). The conduction function is radically affected by the variation of the internal diameter of xylem tracheids (Tyree et al., 1994; Cruiziat et al., 2002; Mc Elrone et al., 2004): the Hagen- Poiseuille law shows that flux in a capillary tube depends on the 4th power of this tube's diameter (Zimmermann 1983; Tyree and Ewers, 1991; Aumann and Ford, 2006). Moreover, anatomical features of wood and particularly tracheid lumen diameter and cell-wall width are strongly related to wood density (Rathgeber et al., 2006). Indeed, the wood density of a wooden sample is a function of the proportion of cell wall in the wood volume (Zobel and Van Buijtenen 1989; Pittermann et al., 2006). Hence variation of wood density may have an impact on conduction properties and on the vulnerability to cavitation.

The objective of this study is thus to compare the variation of Douglas-fir ring density characteristics between sites, clones and year-rings, with the variation of traits recognized to have an effect on tree fitness and related to wood conduction properties. These traits are vulnerability to cavitation (VC) and native axial specific hydraulic conductivity (Ks). VC indirectly measures the effects of induced embolism on Ks (Sperry et al., 1988; Sperry and Tyree 1990). Ks is a measure of the hydraulic efficiency of the xylem in relation to wood's transverse section. For the same pressure gradient in a tube segment, a small increase of the internal diameter strongly increases Ks (Sperry and Tyree 1990; Mc Elrone et al.,. 2004). The 
other factor strongly influencing the value of $\mathrm{Ks}$ is the proportion of embolised tracheids in the xylem since we measure native conductivity. In this work we used a novel method to measure this variable, allowing us to precisely and individually assess $\mathrm{Ks}$ in different tree rings and then to relate its variation to that of tree-ring microdensity variables, as well as to tree's vulnerability to cavitation.

These results are discussed in the frame of the selection potential of Douglas-fir to face the global climate change and of the development of this species breeding program in France.

\section{MATERIAL}

\subsection{Site and material description}

The plant material used in this study is a selection within a clonal experimental design used by Martinez-Meier et al. (2008): three clones (among nine) were selected in two clonal trials planted in two different sites. The two chosen sites are typical of two French regions where Douglas-fir is abundantly planted: Chassenoix, Northeast of Massif-Central, Morvan, and Lartimache, West of Massif-Central, Haute Vienne, Limousin. Both sites, planted by FCBA (Institut Technologique Forêt, Cellulose, Bois et Ameublement. France), were differently affected by the 2003 heat and drought wave: the first was strongly affected, while in Lartimache, the year 2003 was just slightly dryer and warmer than habitually. Trees in Lartimache present larger circumferences than trees in Chassenoix (Fig. 1).

\section{INSERT FIGURE 1}

The three clones were selected by means of their growth characteristics in order to cover a larger variability. While not directly an adaptation trait by itself, growth is obviously related to adaptation. Thus large between-clone differences for growth may indicate differences for 
adaptation. In the absence of direct information, selecting extreme clones for growth is assumed to be a way to select differently adapted clones. Clone 1407 with the larger circumferences in both sites, clone 162 with the smallest circumferences and equal in both sites and clone 1216 between them. (Fig. 1).

For the period 1994-2004 Chassenoix and Lartimache showed similar mean annual precipitations, with $1212 \mathrm{~mm}$ and $1206 \mathrm{~mm}$ respectively, while Lartimache had higher annual means for maximum and minimum temperatures: $16.8^{\circ} \mathrm{C}$ and $6.3^{\circ} \mathrm{C}$ respectively, against $15.3^{\circ} \mathrm{C}$ y $5^{\circ} \mathrm{C}$ in Chassenoix. Particularly, in the year 2003, we found great climatic differences. We computed a Standardized Climatic Index (SCI) to describe the between-site difference of the climate conditions of the year 2003 (Barbu and Popa 2003).

$$
S C I_{2003}=\frac{C I_{2003}-C I_{\chi}}{\text { s.d.CI } I_{\chi}}
$$

Where: $C I_{2003}$ is the Climatic Index of the year 2003, $C I_{\chi}$ is the mean Climatic Index for the period 1994-2004 and s.d.CI $x_{\chi}$ is the standard deviation of the Climatic Index during the period 1994-2004.

This Climatic Index (CI) was computed based on the index of De Martonne (De Martonne,1926), calculated as a function of the cumulated daily maximum temperature ( $T$ max ) and of the cumulated annual precipitation $(P p)$ of the year $i$ as follows:

$$
C I=\frac{T \max }{P p}
$$

For the year 2003 we found in Chassenoix a SCI of $2.51(\mathrm{CI}=7.32)$, while in Lartimache it was only of $0.93(\mathrm{CI}=5.71)$. Regarding the year 2002 we computed in Chassenoix and Lartimache an SCI of only $0.21(\mathrm{CI}=4.97)$ and $0.54(\mathrm{CI}=4.82)$ respectively. 


\subsection{Wood sampling}

During April 2006 we harvested four trees per clone per site (24 trees in total). Of each tree we collected 5 branches of about $2.5 \mathrm{~cm}$ of diameter at the base and we took also a piece of stem $50 \mathrm{~cm}$ long at $2 \mathrm{~m}$ high, to obtain the vulnerability to cavitation curves. We also cut a disk of $10 \mathrm{~cm}$ thick to measure hydraulic conductivity in rings 2002 and 2003, and to obtain X-ray microdensity profiles. All the samples were thoroughly wrapped with wet tissues and were placed into thick black plastic bags in order to avoid dehydration and cavitation.

The disks were immediately taken to INRA Orléans for conductivity and microdensity measurements while the stems and the branches were transported to INRA Clermont-Ferrand for vulnerability to cavitation curves measurements (Fig. 2).

\section{INSERT FIGURE 2}

\section{METHODS}

\subsection{Microdensity profiles}

In this study, wood density variables were assessed using the indirect X-ray method developed by Polge (1966). The microdensity profiles finely describe within and between ring radial wood density variations. The upper and/or lower parts of the disks not used to measure Ks were sawn into four stripes with a double blade saw. These were about $8 \mathrm{~mm}$ width and $1.5 \mathrm{~mm}$ thick and as long as the sample's radius. Then they were air dried up to moisture equilibrium and subsequently analysed by indirect X-ray microdensitometry (Polge 1966). The resulting X-ray films were scanned at 1000 dpi of resolution with 8 bits per pixel. The digitalized images were processed by using WinDENDRO, Regent Instruments Inc., (Guay et al., 1992), obtaining a microdensity profile with a spatial resolution of $25 \mu \mathrm{m}$ (Fig. 3). 


\section{INSERT FIGURE 3}

The last step of the data process used a computer routine written in $\mathrm{R}$ language ( $\mathrm{R}$ Development Core Team 2007) to assess the following ring variables: ring width (RW), mean ring density (MRD), minimum ring density (MID) and maximum ring density (MAD) (Fig. $3)$.

\subsection{Stem and branches vulnerability to cavitation (VC) curves}

In order to obtain the pieces of wood compatible with the measurement equipment, we extracted trunk longitudinal portions making two cuts, in V, with a circular saw. Out of the latter we cut bars of about $0.5 \mathrm{~cm}$ of diameter, with a knife, following the wood grain, which was not always perfectly straight on these trees. This was done in the outermost sapwood portion.

To establish VC curves, we used a technique developed by Dr. H. Cochard and his team at INRA Clermont-Ferrand, France (Cochard 2002; Cochard et al., 2005). Samples were not saturated restoring maximum conductivity in order to avoid cavitation fatigue. Refilling may also leave behind small micro-bubbles that could nucleate cavitation during subsequent stress (Hacke et al., 2001b).

The VC curves were established on the stems and the branches. The measurements conducted on branches were useful to compare the VC curves obtained with the technique used in this study with the VC curves obtained with the techniques used in the previously published articles.

Once the VC curves were constructed, one parameter was calculated to describe their variation: the PLC50 pressure (point of the curve with a 50\% loss of conductivity at a 
determined pressure), calculated according to Domec and Gartner (2001) for stems (PLC50 $\mathrm{S}$ ) and for branches (PLC50 $)$.

\subsection{Axial specific hydraulic conductivity (Ks)}

The discs harvested on the field have been sawn again in order to obtain a central disc of about $25 \mathrm{~mm}$ thick and then have been immediately immersed again into water. Then these disks were sawn perpendicularly in order to get four quadrants and again kept in water. All these manoeuvres were done under a humid atmosphere, acquired by constantly vaporizing water over the samples.

To measure the tree rings axial hydraulic conductivity $(\mathrm{Ks})$, we used a $2 \mathrm{~mm}$ diameter veterinary needle, connected to the end of a water column. The needle was carefully inserted, under the water, into the earlywood of a selected sapwood ring, taking care of having no air bubbles inside it. The other extremity of the $120 \mathrm{~mm}$-long column was connected to a micropipette allowing reading of changes of water volume through time.

The system has been filled with distilled Phloxine coloured water, making reading easier and permitting to permanently verify dripping and absence of air bubbles. Besides, we could verify that coloured water really passed through the sample and arrived exactly to the other side, in the same portion of the ring where the needle was pricked.

Sapwood's specific conductivity (Ks) was calculated according to Darcy's law (Edwards and Jarvis 1982):

$$
k_{s}=\frac{V^{*} L^{*} \eta}{t^{*} A^{*} \Delta P}
$$

where $V$ is the volume of water that went through the sample $\left(\mathrm{m}^{3}\right), L$ is the sample length $(\mathrm{m})$, $\eta$ is the viscosity of water at the temperature at which the experiment was conducted $\left(\mathrm{N} \mathrm{s} \mathrm{m}^{-}\right.$ $\left.{ }^{2}\right), t$ is the time (s), $A$ the cross-sectional area $\left(\mathrm{m}^{2}\right)$ of the needle and $\Delta P$ is the pressure 
difference $(0.0118 \mathrm{MPa})$ between both ends of the sample. The entire cross section of each sample was assumed to be functional sapwood. Measurements were conducted in rings 2002 and 2003. In order to choose and systematize the part of the ring where the needle was going to be inserted we conducted measurements considering different parts of the ring: earlywood, transition between earlywood and latewood and, in few cases, in the latewood part only.

Ks was expressed in $\mathrm{m}^{2}$ as a consequence of separating the viscosity $(\eta)$ from the driving agent in terms of a pressure difference. Thus, Ks is determined only by wood structure and is independent of the nature of the fluid (Domec and Gartner 2002b).

In this study, the samples were not restored to maximum conductivity prior to $\mathrm{VC}$ and $\mathrm{Ks}$ measurements. It implies that $\mathrm{Ks}$ is an indirect measure of the proportion of embolised tracheids in the xylem.

\subsection{Data Analysis}

For PLC50, the existence of significant environmental (site) and genetic (clone) effects was tested using the following ANOVA linear model, through aov function of $\mathrm{R}$ software ( $\mathrm{R}$ Development Core Team, 2007).

$$
y_{i j}=\mu+\alpha_{i}+\beta_{j}+(\alpha \beta)_{i j}+\varepsilon_{i j}
$$

Where: $y_{i j}$ is the PLC50 observed value in the ${ }_{i}$ th site and of the ${ }_{j}$ th clone, $\mu$ is the general mean, $\alpha_{i}$ is the fixed effect of ${ }_{i}$ th site, $\beta_{j}$ is the fixed effect of ${ }_{j}$ th clone, $(\alpha \beta)_{i j}$ is the interaction between ${ }_{i}$ th site and ${ }_{j}$ th clone, and is the $\varepsilon_{i j}$ random error.

The Ks variable did not originally satisfy the conditions of the linear model. Transformation methods were unsuccessful to normalize Ks values. Therefore the existence of significant environmental (site and year) and genetic (clone) effects was tested using a non parametric 
Kruskall-Wallis analysis of variance using kruskal.test function in $\mathrm{R}$ software ( $\mathrm{R}$ Development Core Team 2007).

For the ring variables we used the following ANOVA model, incorporating the year effects, through aov function in R software (R Development Core Team 2007):

$$
y_{i j k}=\mu+\alpha_{i}+\beta_{j}+\delta_{k}+(\alpha \beta)_{i j}+(\alpha \delta)_{i k}+(\beta \delta)_{j k}+\varepsilon_{i j k}
$$

Where: $y_{i j k}$ is the ring variable observed, $\mu$ is the general mean, $\alpha_{i}$ is the fixed effect of ${ }_{i}$ th site, $\beta_{j}$ is the fixed effect of ${ }_{j}$ th year, $\delta_{k}$ is the fixed effect of ${ }_{k}$ th clone, $(\alpha \beta)_{i j}$ is the interaction between ${ }_{i}$ th site and ${ }_{j}$ th year, $(\alpha \delta)_{i k}$ is the interaction between ${ }_{i}$ th site and ${ }_{k}$ th clone, $(\beta \delta)_{j k}$ is the interaction between ${ }_{j}$ th year and ${ }_{k}$ th clone, and $\varepsilon_{i j k}$ is the random error.

\section{RESULTS}

\subsection{Microdensity parameters}

The values obtained for RW, MRD, MID and MAD are represented in figure 4 . RW is smallest for clone 162 (even though it is not significant for Chassenoix 2002 tendencies are the same). Ring 2003 is always narrower than ring 2002. MRD and overall MAD are significantly and especially low in 2003 in Chassenoix. Clone 162 showed a significantly higher MID in both sites for both year-rings.

\section{INSERT FIGURE 4}

We found a significant year effect for all ring variables and a significant clone effect for all ring variables except for MAD, while the site effect was significant for MRD and MAD. (Table 1). 


\section{INSERT TABLE 1}

\subsection{Stem and branches vulnerability to cavitation (VC) curves}

Figure 5 show the VC curves constructed for each site and each clone. Figures $5 \mathrm{a}$ and $5 \mathrm{~b}$ show the VC curves for the stems, and figures $5 \mathrm{c}$ and $5 \mathrm{~d}$ for the branches. We carried further analysis (not shown here) showing that the branches were significantly $(\mathrm{P}<0.001)$ less vulnerable than the stems in both sites and for all three clones.

\section{INSERT FIGURE 5}

The general mean of Douglas-fir's PLC50 srowing in two different environments was -2.45 $\mathrm{MPa} \pm 0.42$. Table 2 shows the results of the ANOVA computed for PLC50 . The clone effect was significant, but not the site effect, neither the site $\times$ clone interaction effect. We found also that clone 162 stems'were significantly less vulnerable to cavitation than stems of the other two clones.

\section{INSERT TABLE 2}

The same analysis of variance conducted separately in both sites demonstrated that the clone effect was significant only in Lartimache. Through the analysis of PLC50 $\mathrm{B}$ we found significant (Table 2) site and clone effects. The site $\times$ clone interaction effect was not significant (Table 2). 


\subsection{Axial specific hydraulic conductivity $(\mathrm{Ks})$}

Transversal cuts of the sample in the area where needle was inserted permitted us to verify that there was no lateral movement of dye (Phloxine) during the measurement of Ks.

The Ks results presented in this work were analysed for the measurements conducted in the earlywood part of the ring only. Latewood conductivity was so low that it could not be accurately quantified with our method.

The main source of variation for Ks measured in the earlywood of the rings 2002 and 2003 in Douglas-fir was the site (Fig. 6).

\section{INSERT FIGURE 6}

The Kruskal Wallis non-parametric analysis of variance showed strongly significant differences between sites $(\mathrm{P}<0.001)$ and between years in both sites $(\mathrm{P}<0.001)$. There were significant differences among clones in Chassenoix for both years $(\mathrm{P}=0.01$ and $\mathrm{P}<0.001$ for the years 2002 and 2003 respectively) and in Lartimache only for year $2002(\mathrm{P}<0.05)$. In Chassenoix, the site more affected by the 2003 drought and heat wave, the clone 162 (selected for its slow growth and high wood density) showed significantly higher Ks than clones 1216 and 1407 in 2002 and 2003 (Fig. 7).

The difference was spectacularly high in 2003, with the Ks of clone 162 being more than a hundred times higher than the Ks of clones 1216 and 1407.

\section{INSERT FIGURE 7}




\section{DISCUSSION}

Up to now, most VC curves published for woody plants and for Douglas-fir in particular were obtained from measurements obtained on seedlings and on branches and roots (Cochard 1992; Sperry and Ikeda 1997;Kavanagh et al. 1999). As far as we know, little information is available from direct measures obtained on stem xylem of mature trees (Domec and Gartner, 2003). Our measurements of PLC50, achieved on wood samples collected on relatively mature (22 year-old) trees, are consistent with those by other authors (Domec and Gartner, 2001) for the same species. We agree with these authors in the fact that branches are significantly less vulnerable than stems. The values that we measured for PLC50 $\mathrm{s}$. and PLC50 $\mathrm{B}$ are both higher than those measured by Stout and Sala (2003) and by Kavanagh et al. (1999), who used seedlings or saplings or terminal shoots on adult trees. Moreover, these authors used different methods of embolism induction and of measurement than the ones we used during this study. In spite of these differences, we all found that stem xylem is the most vulnerable part of Douglas-fir aerial parts. Branch wood is formed of shorter, narrower tracheary elements and is thus generally denser than stem wood (Gartner, 1995). These different anatomical characteristics could confer differential hydraulic properties to branch wood, explaining at least a part of the observed difference.

Analyzing PLC50 data, we found that the site effect was significant for PLC50 $\mathrm{B}$ but not for PLC50s. In contrast, we found significant differences among clones for both traits, with no significant genotype-by-environment interaction. The analysis of variance conducted for PLC50 separately in both sites demonstrated that the clone effect was significant only in Lartimache (not shown here). According to this result, in Lartimache, the clone 162 was the most resistant to cavitation while the clone 1216 was the most vulnerable. In Chassenoix, while not significant, the same tendency was observed. PLC50 $\mathrm{B}$ shows also that clone 1216 is the most vulnerable in both sites. 
The other xylem hydraulic property measured in this study is Ks. We used a novel and useful method, permitting to compare Ks between year-rings 2002 and 2003. The introduction of coloured water showed no evidence of radial movement. This is consistent with the fact that, in conifers, most inter-tracheid pits are on radial rather than tangential cell walls, facilitating water movement within a growth ring but limiting it between growth rings (Domec et al., 2005). To our opinion, this demonstrates that rings are hydraulically isolated, at least for the short distance between samples' ends.

Only earlywood Ks measurements were analysed. Attempts to measure Ks in latewood confirmed that, as already shown by Domec and Gartner (2002), latewood conductivity could be neglected compared to earlywood conductivity in Douglas-fir.

Conductivity measured in Lartimache was comparable to the one measured by other authors (Domec and Gartner 2002). The conductivity measured in Chassenoix was a hundred times smaller $\left(3.2 \pm 6.3 \times 10^{-14} \mathrm{~m}^{2}\right)$, even smaller than the one measured by Domec and Gartner (2002) in latewood: this suggests that an important proportion of tracheids in the Chassenoix wood samples were already embolised at the date of sample collection. This is certainly a direct consequence of the 2003 heat and drought wave, which was found to be much more intense in Chassenoix than in Lartimache. The twig mortality observed in Chassenoix was certainly related to this embolisation. In Chassenoix, the effect of climate was probably accentuated by the sandy nature of the soil, much dryer than in Lartimache. These findings suggest that the results in Chassenoix and Lartimache should be differently interpreted. In Lartimache, the conduction properties of the xylem of the collected samples were probably preserved after the 2003 heat and drought wave. The VC curves and the Ks measurements can thus be reliably interpretable in this site as inherent properties of the observed trees.

The results of the analysis of PLC50 $\mathrm{B}, \mathrm{PLC} 50_{\mathrm{S}}$ and $\mathrm{Ks}$ in Lartimache demonstrate that there is most of the time, a significant clone effect for these variables, except for Ks in ring 2003. The 
increased resistance to cavitation of clone 162 goes together with a lower growth rate in both sites (Fig.1). Moreover clone 162 shows a tendency to produce wider rings in Chassenoix than in Lartimache (Fig.Xa) contrary to clone 1407 that presents wider rings in Lartimache and to clone 1216 that presents equal ring width in both sites. In Lartimache, Ks was significantly higher in 2003 (Fig. 6). In a first approach, this may seem contradictory with the higher densities (MRD, MID and MAD) measured in year-ring 2003 compared to year-ring 2002. Tracheary elements with narrower lumens and thicker cell walls corresponding to higher MRD, MID and MAD are expected to be less conductive. But in 2003 atmospheric demand was much higher than in 2002. Thus an unknown proportion of tracheids may have been embolised in year-rings 2002 and 2003. Because the lower density of year-ring 2002 is likely to make it more vulnerable to cavitation, the proportion of embolised tracheids could have been higher in year-ring 2002 than in year-ring 2003, leading finally to a higher measured conductivity in year-ring 2003 in Lartimache. Such a hypothetical elucidation requires for validation new accurate observations, like direct measurement of embolisation rates in the different year-rings. We think also that refilling experiments under pressure could have also helped elucidating this. Refilling experiments measure potential specific conductivity, while our experiment measures native specific conductivity: the difference between both types of measurements would estimate the cavitation rate.

In Chassenoix there was a significant clone effect for Ks. The conductivity of clone 162 was more than a hundred times higher than the conductivity of the other two clones. This suggests that this clone suffered much less embolism than the other two. This observation is strongly supported by the fact that, according to the results obtained in Lartimache, the clone 162 is more resistant to cavitation. In Chassenoix, the observed range of variation for Ks was very different than in Lartimache. Most part of the observed variation was more likely explained by the proportion of embolised tracheids rather than by the native conductivity of the wood. 
On the other hand, Ks results could be also affected by the fact that we measured always in the same area determined by the needle's diameter. The needle was pricked in earlywood only. Nevertheless there are some anatomy variations within earlywood, as well as a more or less gradual transition from earlywood to latewood. The transition zone between earlywood to latewood may have affected the Ks measurements in the smaller rings.

The results of the microdensity analysis show that the clone 162 has also the highest MRD and MID among the three studied clones. These results support the idea proposed by several authors (Tyree et al., 1994; Stratton et al., 2000; Hacke et al., 2001a; Cruiziat et al., 2002; Bucci et al., 2004), that thicker cell walls and smaller diameter lumens, corresponding to higher density wood, increase resistance to drought-induced cavitation and thus help trees to protect their hydraulic system. Our demonstration of the existence of a significant clone effect for $\mathrm{PLC} 50_{\mathrm{S}}, \mathrm{PLC} 50_{\mathrm{B}}$ and Ks strongly supports the idea that there exists a genetic control for resistance to cavitation and for conductivity in Douglas-fir. The well-known existence of a high genetic control for wood density (Zobel and Jett 1995) also supports this idea. Such a genetic control indicates that there is, in the Douglas-fir populations introduced in France, a potential to adapt to extreme climate events like the 2003 heat and drought wave. This potential could be used in the frame of the Douglas-fir breeding program to select for more drought-resistant genotypes. This is important in the frame of the global climate change, for which an increase of the frequency and of the severity of drought waves is forecasted. Further investigations on larger tree populations are necessary to confirm these trends and to precisely estimate the degree of this genetic control. Because direct measurement of hydraulic traits is expensive, destructive and time consuming, it seems necessary, now, to precisely investigate on large, genetically structured populations, the relationships between, on one hand, resistance to cavitation and conductivity and, on the other hand, tracheid radial dimensions depicted by anatomy and/or microdensity observations. 


\section{CONCLUSIONS}

Our results support the opinion that there is a relationship between wood density and wood hydraulic properties. Moreover, these results demonstrate that among the three selected clones of the study, the most resistant to cavitation is the one with the highest mean and minimum ring density.

The results of our study support the idea that genetic variation of wood density components has, to some extent, an adaptive meaning: under extreme drought conditions, Douglas-fir trees with a higher wood density have a higher probability to survive than trees with a lower density. Since variation of wood density components is from moderately to highly genetically controlled, extreme droughts may be regarded as selection events tending to increase the wood density and thus the resistance to drought of future Douglas-fir generations. To what extent this adaptation potential is compatible with the on-going global climate change? Studies recording longer-term response of Douglas-fir trees of variable genetic origins, including rates of mortality under changing environmental conditions are the required next steps to try to answer this question.

\section{AKNOWLEDGEMENTS}

This research was partly funded by Project Alfa II-266 GEMA (GEnética de la MAdera), supported by the European Commission. Genetic material that was used in this study was provided by FCBA (formerly AFOCEL). We are grateful to I.N.R.A and I.N.T.A, particularly to Dr. T. Schlichter and Dr. L. Gallo. The authors gratefully acknowledge Leopoldo Sanchez for his helpful comments and support, Frédéric Millier for the X-ray images and Jean-Yves Gautry for his advice and help in the field. 


\section{REFERENCES}

Aumann, C.A., Ford, E.D., 2006. Simulation of effects of wood microstructure on water transport. Tree Physiology 26, 285-301.

Bacelar, E.A., Moutinho-Pereira, J.M., Gonçalves, B.C., Ferreira, H.F., Correia, C.M., 2007. Changes in growth, gas exchange, xylem hydraulic properties and water use efficiency of three olive cultivars under contrasting water availability regimes. Environmental and Experimental Botany 60, 183-192.

Barbu, I., Popa, I., 2003. Drought risk monitoring research program in Romanian forest. In: Impacts of the Drought and Heat in 2003 on Forest. Scientific Conference 17-19 November 2004. Freiburg, Germany, 66-67.

Bréda, N., Granier, A., Aussenac G., 2004. La sécheresse de 2003 dans le contexte climatique des 54 dernières années: analyse écophysiologique et influences sur les arbres forestiers. Rev. For. Fr. 56, 109-131.

Bréda, N., Huc, R., Granier, A., Dreyer, E., 2006. Temperate forest trees and stands under severe drought: a review of ecophysiological responses, adaptation processes and longterm consequences, review. Annals of Forest Sciences 63, 625-644.

Bucci, S., Goldstein, G., Meinzer, F., Scholz, F., Franco, A., Bustamante, M., 2004. Functional convergence in hydraulic architecture and water relations of tropical savanna trees: from leaf to whole plant. Tree Physiology 24, 891-899.

Cochard, H., 1992. Vulnerability of several conifers to air embolism. Tree Physiology 11, $73-83$

Cochard, H., 2002. A technique for measuring xylem hydraulic conductance under high negative pressures. Plant, Cell and Environment 25, 815-819. 
Cochard, H., Damour, G., Bodet, C., Tharwat, I., Poirier, M., Améglio, T., 2005. Evaluation of a new centrifuge technique for rapid generation of xylem vulnerability curves. Physiologia Plantarum 124, 410-418.

Cruziat, P., Cochard, H., Améglio, T., 2002. The hydraulic architecture of trees: main concepts and results. Annals of Forest Sciences 59, 723-752.

De Martonne, E., 1926. L'indice d'aridité, Bulletin de l'Association des géographes français, 9, 3-5.

Département de la Santé des Forêts 2004. Sécheresse et canicule de l'été 2003. Quelle incidence visuelle sur les peuplements forestiers? Information Santé des Forêt, http://www.agriculture.gouv.fr/spip/IMG/pdf/isfweb_long.pdf, 8 p.

Domec, J.C, Gartner, B.L., 2001. Cavitation and water storage in bole segments of mature and young Douglas-fir trees. Trees 15, 204-214

Domec, J. C., Gartner, B., 2002a. How do water storage differ in coniferous earlywood and latewood? Journal of Experimental Botany 53, 2.369-2.379.

Domec, J.C, Gartner B.L., 2002b. Age- and position-related changes in hydraulic versus mechanical dysfunction of xylem: inferring the design criteria for Douglas-fir wood structure. Tree Physiology 22, 91-104.

Domec, J-C., Gartner, B.L., 2003. Relationship between growth rates and xylem hydraulic characteristics in young, mature and old-growth ponderosa pine trees. Plant Cell Environment 26, 471-483.

Domec, J-C., Meinzer, F.C., Gartner, B.L., Woodruff, D., 2005. Transpiration-induced axial and radial tension gradients in trunks of Douglas-fir trees. Tree Physiology 26, 275-284.

Edwards W., Jarvis P. 1982. Relations between water content, potential and permeability in stems of conifers. Plant Cell and Environment 5, 271-277. 
Gartner, B. L., 1995. Plant Stems: Physiology and Functional Morphology. Academic Press, San Diego, 440 pp.

Guay, R., Gagnon, R., Morin, H., (1992). A new automatic and interactive tree ring measurement system based on a line scan camera. The Forestry Chronicle 68, 138-141.

Hacke, U., Sperry, J., Pockman, W., Davis, S., Mc Culloh, K., 2001a. Trends in wood density and structure are linked to prevention of xylem implosion by negative pressure. Oecologia $126,457-461$.

Hacke U., Stiller, V., Sperry, J., Pittermann, J., Culloh, K., 2001b. Cavitation Fatigue. Embolism and refilling cycles can weaken the cavitation resistance of xylem. Plant Physiology 125, 779-786.

Kavanagh, K.L., Bond, B.J., Aitken, S.N., Gartner, B.L., Knowe, S., 1999. Shoot and root vulnerability to xylem cavitation in four populations of Douglas-fir seedlings. Tree Physiology 19, 31-37.

Levinson, D. H., Waple, A. M., 2004. State of the Climate in 2003. Bulletin of the American Meteorological Society 85, $72 \mathrm{p}$.

Martinez Meier, A., Sanchez, L., Dalla Salda, G., Pastorino, M.J., Gautry, J.Y., Gallo, L.A., Rozenberg, P., 2008. Genetic control of Douglas-fir (Pseudotsuga menziesii (Mirb.) Franco) tree-ring response to the 2003 heat-wave in France. Annals of Forest Sciences 65, 1. Available in: www.afs-journal.org.

McDowell, N., Pockman, W.T., Allen, C.D., Breshears, D.D., Cobb, N., Kolb, T., Plaut, J., Sperry, J., West, A., Williams, D.G., Yepez, E.A., 2008. Mechanisms of plant survival and mortality during drought: why do some plants survive while others succumb to drought? New Phytologist 178: 719-739 
McElrone, A.J, Pockman, W.T., Martínez-Vilalta, J., Jackson, R.B., 2004. Variation in xylem structure and function in stems and roots of trees to $20 \mathrm{~m}$ depth. New Phytologist $163,507-517$.

Meehl, G., Tebaldi, C., 2004. More Intensive, More Frequent, and Longer Lasting Heat Waves in the 21st Century. Science 305, 994.

Pittermann, J., Sperry, J.S., Wheeler, J.K, Hacke, U.G., Sikkema, E.H., 2006. Mechanical reinforcement of tracheids compromises the hydraulic efficiency of conifer xylem. Plant, Cell \& Environment 29, 1618-1628.

Polge, H., 1966. Etablissement des courbes de variations de la densité du bois par exploration densitométrique de radiographies d'échantillons prélevés à la tarière sur des arbres vivants. Application dans les domaines technologiques et physiologiques. Thèse de doctorat, Université de Nancy 215p.

R Development Core Team, 2007. A language and environment for statistical computing. R Foundation for Statistical Computing, Vienna, Austria, ISBN 3-900051-07-0, http://www.R-project.org.

Rathgeber, C.B.K., Decoux, V., Leban, J-M., 2006. Linking intra-tree-ring wood density variations and tracheid anatomical characteristics in Douglas fir (Pseudotsuga menziesii (Mirb.) Franco). Annals of Forest Science 63, 699-706.

Rebetez, M., Mayer, H., Dupont, O., Schindler, D., Gartner, K., Kropp, J. P., Menzel, A., 2006. Heat and drought 2003 in Europe: a climate synthesis. Annals of Forest Science 63, $569-577$.

Rozenberg, P., Pâques, L., 2004. Evidence of the effect of the climate of year 2003 on Douglas-fir and larch wood formation in France. In: proceedings of conference "Impacts of the Drought and Heat in 2003 on Forests". Scientific Conference 17-19 November 2004. Freiburg, Germany, 5738 
Sperry, J.S., Ikeda, T., 1997. Xylem cavitation in roots and stems of Douglas-fir and white fir. Tree Physiology 17:275-280

Sperry, J.S., Hacke, U.G., Pittermann, J., 2006. Size and function in conifer tracheids and angiosperms vessels. American Journal of Botany 93, 1490-1500.

Sperry, J.S \& Tyree, M.T., 1990. Water-stress-induced xylem embolism in three species of conifers. Plant, Cell \& Environment 13, 427-436.

Sperry, J.S., Donelly, J.R., Tyree, M.T., 1988. A method for measuring hydraulic conductivity and embolism in xylem. Plant, Cell \& Environment 11, 35-40.

Stratton, L., Goldstein, G., Meinzer, F, 2000. Stem water storage capacity and efficiency of water transport: their functional significance in a Hawaiian dry forest. Plant, Cell \& Environment 23, 99-106.

Stout, D.L., Sala, A., 2003. Xylem vulnerability to cavitation in pseudotsuga menziesii and pinus ponderosa from contrasting habitats. Tree Physiology 23, 43-50.

Tyree, M.T., Ewers, F.W., 1991. Tansley Review 34. The hydraulic architecture of trees and other woody plants. New Phytologist 119, 345-360.

Tyree, M., Kolb, K., Rood, S., Patiño, S., 1994.Vulnerability to drought-induced cavitation of riparian cottonwoods in Alberta: a possible factor in the decline of the ecosystem?. Tree Physiology 14, 455-466.

Zimmermann, M.H., 1983. Xylem structure and the ascent of sap. Springer-Verlag, New York, USA, $143 \mathrm{p}$.

Zobel B.J. \& Jett, J.B. 1995. Genetics of wood production. Springer-Verlag, New York.

Zobel, B.J, van Buijtenen, J., 1989. Wood variation its causes and control. Germany. Springer-Verlag Berlin Heidelberg, 363 pp. 


\section{FIGURE LEGENDS}

Figure 1 Trees' circumferences at breast height for each clone in each site

Figure 2 Sample preparation and destination. We collected 5 branches, a piece of stem of about $50 \mathrm{~cm}$ long and a disk of about $10 \mathrm{~cm}$ thick per tree. Branches and the $50 \mathrm{~cm}$ piece were used to build vulnerability to cavitation curves at INRA Clermont-Ferrand. The disks were used to measure axial hydraulic conductivity in rings 2002 and 2003, and to obtain X-ray microdensity profiles at INRA Orléans.

Figure 3 Example of a microdensity profile of a Lartimache tree. Arrows show: MRD (Mean ring density), MAD (Maximum density) and MID (Minimum density) in different tree-rings. 2003 tree-ring is narrower than the 2002 tree-ring in Lartimache, 2003 MAD is higher than that of 2002 .

Figure 4a, 4b, 4c and 4d Ring width (RW), mean ring density (MRD), minimum ring density (MID) and maximum ring density (MAD) respectively. Mean values and standard error per clone and per year in each site. Different letters show groups with significant differences $(\mathrm{P}<$ $0.05)$ between clones in a site within a tree-ring.

Figure 5 Vulnerability to cavitation (VC) curves: percentage loss of conductivity (PLC) as a function of the xylem pressure $(\psi)$, for the three Douglas-fir clones in each site. Figure 5a and $5 \mathrm{~b}$ show VC curves for the stems, and Figures $5 \mathrm{c}$ and $5 \mathrm{~d}$ for the branches. The branches were significantly $(\mathrm{P}<0.001)$ less vulnerable than the stems in both sites and for all three clones. 
Figure 6 Specific conductivity (Ks) according to the sources of variation. The horizontal solid line represents the Ks overall mean for the two sites, two years and three clones. Site is the source with the grater variation. Ks in Chassenoix was a hundred times lower than in Lartimache. Even if the other two sources of variation (year and clone) seem to be less important significant differences were found between years in both sites $(\mathrm{P}<0.001)$ and among clones in Chassenoix for both years $(\mathrm{P}=0.01$ and $\mathrm{P}<0.001$ for the years 2002 and 2003 respectively) and in Lartimache only for year $2002(\mathrm{P}<0.05)$.

Figure 7 Specific conductivity (Ks) per clone and per year in each site with standarddeviation bars showing the Kruskall-Wallis grouping. Different letters show groups with significant differences $(\mathrm{P}<0.05)$ 


\section{TABLES}

Table 1 Results of fixed effect analysis of variance (associated probability) for ring width (RW), mean ring density (MRD), minimum ring density (MID) and maximum ring density (MAD). Df = degrees of freedom.

\begin{tabular}{|c|c|c|c|c|c|c|c|c|}
\hline Variable & Df & RW & & MRD & & MID & & MAD \\
\hline Site & 1 & 0.8587 & & $<2.2^{-16}$ & $* * *$ & 0.8674 & & $3.4710^{-8 * * *}$ \\
\hline Year & 1 & $1.3430^{-8}$ & $* * *$ & 0.0030 & $* * *$ & $2.786^{-1}$ & $* * *$ & $1.685^{-13} * * *$ \\
\hline Clone & 2 & $<2.2^{-16}$ & $* * *$ & $6.2640^{-14}$ & $* * *$ & $<2.2^{-16}$ & $* * *$ & 0.1312 \\
\hline Site* year & 1 & 0.9455 & & $<2.2^{-16}$ & $* * *$ & 0.1335 & & $<2.2^{-16} \quad * * *$ \\
\hline Site*clone & 2 & $1.5760^{-5}$ & $* * *$ & 0.0484 & $*$ & 0.0019 & $* *$ & 0.4933 \\
\hline Year*clone & 2 & 0.8419 & & 0.0123 & * & 0.2122 & & 0.1877 \\
\hline
\end{tabular}

Sig. level: $*=P<0.05, * *=P<0.01, * * *=P<0.005$

Table 2 Results of fixed effect analysis of variance (associated probability) for site, clone and site*clone interaction for PLC50 5 and PLC50 8 . Df $=$ degrees of freedom.

\begin{tabular}{lcll}
\hline Variable & Df & PLC50 & PLC50 \\
\hline Site & 1 & 0.8769 & $0.0014 \quad * *$ \\
Clone & 2 & $0.0007 * * *$ & $2.8497^{-7} * * *$ \\
Site*clone & 2 & 0.1032 & 0.8699 \\
\hline
\end{tabular}

Sig. level: $*=P<0.05, * *=P<0.01, * * *=P<0.005$ 